\title{
Solid Waste Management: A Socio-Economic Perspective of Urban and Peri-Urban Communities in Honiara
}

\author{
Kofi Otumawu-Apreku* \\ Department of Fisheries Studies, The Solomon Islands National University, Solomon Islands
}

Submission: August 20, 2020; Published: September 15, 2020

*Corresponding author: Kofi Otumawu-Apreku, Department of Fisheries Studies, Faculty of Agriculture, Fisheries \& Forestry, the Solomon Islands National University.

Abstract

The risks of poor waste management are multi-dimensional, including environmental, social, economic, and health. The consequences are particularly acute, in the context of developing countries. The Solomon Islands' National Solid Waste Management Strategy outlines the challenges, essentially in urban and peri-urban centers. Quantification of solid waste generation in urban and peri-urban centers across the nation, alongside the related attitudinal, social and economic impacts, remain largely unknown. Without proper understanding of the subject, attempts to solve the problem can, at best, be adhoc and are likely to be unsustainable. This paper provides an assessment of the solid waste management problem, and establishes the associated attitudinal and behavioral challenges, as well as the social and economic costs. I find that while awareness and concern for the environment reduce waste generation and positively impact household income, willingness to purchase less disposable plastic products, though reduces waste volume, negatively affects household income. The findings are expected to provide guidance for waste management policies in urban and peri-urban centers across the nation.

Keywords: Solid waste; Multi-dimensional; Quantification; Multivariate; Policy

\section{Introduction}

Rising volumes of solid waste in towns and cities around the world continue to raise public concern. The problem is often ascribed to population rise, increase in human activities, change in consumption patterns and attitudinal challenges. Urbanization and over-concentration of human population are identified as major factors exacerbating the solid waste challenge [1-3]. Added to the complexity of the problem is the rapid technological and economic advancement in modern times; a phenomenon that has contributed to changes in life-styles, tastes, social preferences, as well as the nature and volume of both industrial and domestic waste. Solid waste in developing countries has changed in both composition and quantity, increasing from few kilograms to tonnage proportions [4-6]. Even though solid waste management continues to pose serious challenges in underdeveloped thirdworld countries, reliable statistics and information on the related underlying factors generally remain unavailable [7]. The waste pressure from household and industrial sources, needs concerted effort to improve collection coverage and operational efficiencies $[8,9]$. The effort requires reliable information about the volume of waste, characteristics of waste generated, as well as attitudinal and behavioral challenges in waste management at all levels. In the context of the developing world, the literature has largely focused on collection methods, willingness to pay, poor waste disposal, and the public good nature of solid waste management $[9,10]$, without paying much attention to what can be considered the antecedent of the problem; attitudinal challenges and waste quantities, particularly that of the household $[11,12]$.

In developing countries, the household is considered an important stakeholder in the waste management discourse [4,11-13]. Miezah et al. [14]; for example, estimate that the household generates between 50 and $55 \%$ of municipal waste, with the underpinning attitudinal, behavioral and socio-economic factors, compounding the complexity of the problem and being serious barriers to meaningful solutions $[5,11,14]$. Knowledge 
of the actual volume of household waste, the related attitudinal and behavioral challenges, however, largely remain unknown in many developing countries [9]. For example, individual and household attitude towards the use of disposable products such as polypropylene consumer products, willingness to adopt the use of environmentally friendly options, etc, have not received the much-needed attention in the literature. This paper uses urban and peri-urban communities, in and around Honiara, the capital city of the Solomon Islands, to estimate waste volumes generated at the household level, and establishes the associated attitudinal, behavioral, health costs, social and economic challenges, as its major contribution to the developing country waste management discourse. In addition, the paper examines the characteristics of waste generated and the significant factors that can potentially help address the waste management challenge. This is expected to augment the necessary information required to formulate the appropriate national solid waste management policy guide [15] for Honiara city and its environs, and possibly for other developing nations facing similar challenges.

In the context of the Solomon Islands, like elsewhere in the developing world, the informal sector constitutes nearly $60 \%$ of the national economy, with socio-economic activities largely limited to the household level [16], making the household a significant source of waste generation. Rural-urban influx is also rising, with migrants scattered around urban and peri-urban areas of Honiara [17]. Coming into force in 2003, the Solomon Islands Environmental Act 1998 makes provisions to promote waste management practices that ensure health, welfare, convenience, as well as comfort of its citizens and the environment in which they reside [18]. Adding to that, the country being party to a number of international conventions on resource extraction and environmental pollution, such as the Convention on Persistent Organic Pollutants (2004), strives to promote environmental sanity across the nation. The success of the effort will, among other things, largely depend on availability of accurate and more reliable information that sufficiently informs practical policy options.

Globalization, changing lifestyles, consumption patterns, and the attendant increase in packaged and processed goods, are found to compound the solid waste management challenge in both rural and urban settlements [7]. In inland and coastal areas, poor waste management is a serious source of pollution; huge volumes of waste continue to be discarded in water bodies and along ocean shorelines $[9,19]$. In the Solomon Islands, solid waste generation is considered an urgent and challenging issue, with damaging environmental dimensions and serious health related problems. The issue, however, largely remains unresolved [17]. To achieve the objectives outlined in the National Solid Waste Management Strategy (NSWMS, 2016-2026), the Ministry of Environment, in collaboration with bilateral and multi-lateral organizations, initiated a number of projects aimed at addressing the solid waste management (SWM) challenge [15]. Though the projects were multi-pronged and included assessment, waste minimization, disposal and collection measures, awareness and education, the problem in its complexity still persists. For example, the Mataniko river basin pollution project, years after the clean-up, the problem remains a huge challenge due to uncontrolled waste disposal and poor garbage collection [15]. Limited awareness and knowledge, coupled with lack of cooperation and poor attitudinal problems, at the household and private business facilities, have exacerbated the challenge [17].

It is evident from the NSWMS (2016-2026) document that, like in Nigeria, Cameroon, Kenya, and Uganda [20-23], the Solomon Islands is experiencing SWM failures, particularly in its urban and peri-urban environs. In addition to the stylized challenges experienced in the developing world, such as financial limitations, poor institutional structures, inadequate resources [24], the problem in the Solomon Islands is further compounded by attitudinal challenges, lack of cooperation at the individual level, limited awareness and insufficient waste management knowledge among the citizenry, as well as inadequate scientific based information to guide policy [17].

The rest of the paper is organized as follows. Section 2 provides background details of the communities investigated, with section 3 explaining the methods employed in the paper. Section 4 details the data collection process. In section 5 the empirical application and results are discussed. Policy relevance of evidence-based knowledge of the volume of solid waste generated at household level is highlighted in section 6 . The paper concludes by emphasizing the need to address attitudinal and behavioral challenges in solid waste management at the household level and provides future research direction.

\section{Background}

The study covers five selected urban and peri-urban settlements in and around Honiara. These communities are typical of settlement patterns in Honiara; high population densities and unplanned settlement patterns are a common feature. Settlement in the city is not entirely segregated; with the exception of two communities, Tasahe and Ngossi, which are predominately middle and upper class, all others are a mix of lower- and upperincome groups, residing side-by-side. The Solomon Islands, the third largest archipelago in the South Pacific region (nearly 28,000 sq. kms.), comprises of about 992 small islands, with just about a third currently inhabited. Guadalcanal, the largest (about 5,348 sq. kms.) of 9 administrative provinces, lying within latitude 90 South and longitude 1590 East (Figure 1), hosts Honiara. The nation's population, by the $2012 / 13$ official estimates, is projected at over 600,000 , with a young fast-growing population in towns and cities of the 9 provincial capitals [16]. Typical of developing nation state capitals, Honiara is by far the largest recipient of migrant influx from the other islands and provinces. The resultant effect is the increasing waste management challenges in the city and its environs. 


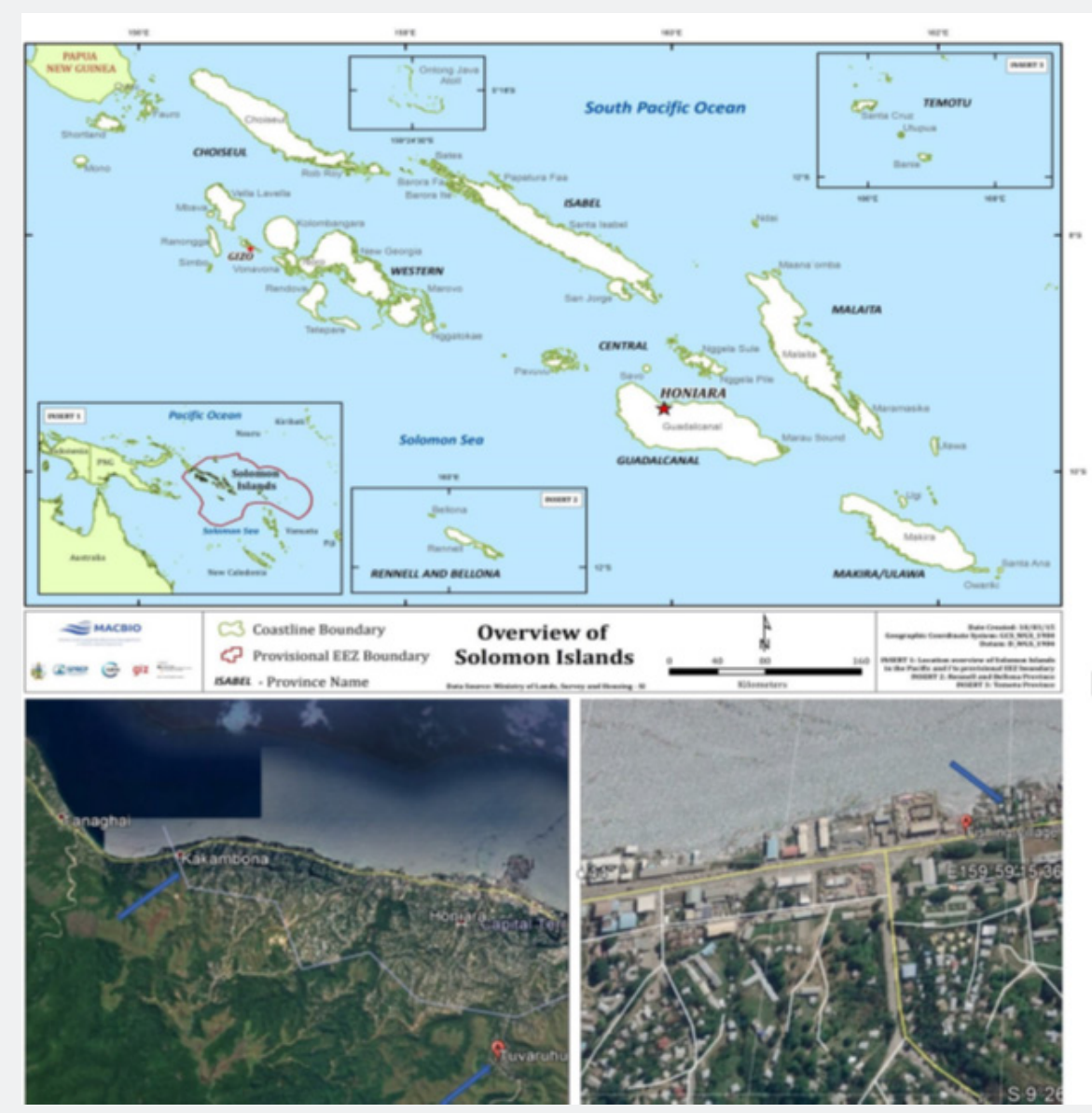

Figure 1: A map of the Solomon Islands and parts of Honiara, the state capital Source: Ministry of Lands, Survey and Housing, Solomon Islands.

The selected communities include: Fishing Village; Lorde Howe; Kaibia Valley; Tuvaruhu (Zone 5); and Kakabona. Fishing Village, Lorde Howe, and Kaibia Valley are urban communities within Honiara municipality. Kakabona and Tuvaruhu (Zone 5), on the other hand, are peri- urban communities, sited at the fringes of Honiara. Fishing Village, located in the Vura ward of Honiara City Council, covers an area of about 4 hectares, and sits on the coastline, 5 meters from the high water mark, stretching about 500 meters along the main highway, east of Honiara. Population density of this community is about 115 persons/hectare, with an average household size of 8 persons [25]. The settlement is vulnerable to erosion, storm surge, wave action, and sea-level rise hazards [26]. Economic activities of the community have shifted significantly from the traditional dependence on fishing to other sources of income. Decline in fishing activities, as traditional income source, is generally attributed to significant reduction in fish catch [26]. Recent household income sources have included engagement in the public and private sectors, self-employment, including the sale of goods and services, in the informal sector [16]. Available figures put the distribution of active labor force in the settlement as follows: $14 \%$ working in the civil service and other state owned enterprises; $16 \%$ in the private sector; about $42 \%$ engaged in self-employed private enterprises of all kinds, producing basic goods for sale on the local market; and $6 \%$ in unpaid family work [26].

Lord Howe, also known as the Ontong Java settlement, is situated in the Mataniko ward, sitting along the coast line where the Mataniko river empties into the ocean, through its delta ${ }^{1}$, just about 5 meters from the high water mark [27]. The settlement covers a total landmass of 2.8 hectares, with a population density of 223 persons/hectare, nearly nine times the city average of 26 persons/hectare, and 8 persons/household on average [15]. Lord Howe and Fishing Village are among four settlements designated by the UN-Habitat as 'hotspots' due to their hazard exposure and vulnerability [28]. The population density in the community is considered the highest among the 'hotspots'. According to Trundel

${ }^{1}$ Mataniko is a major river running through the north-central divide of Honiara city, and empties into the ocean, through Lorde Howe on the southern edge of the coast. 
\& Mcevoy [28], a common feature of the 'hotspots' is the high population density, generally over 100 persons/hectare, with $80 \%$ of households without toilet facilities. Like Fishing Village, Lord Howe is exposed to a number of hazards, with flooding being a major threat. Flooding in the settlement worsens the sanitation conditions, and increases skin and gastro-intestinal diseases, among others [26]. About $41 \%$ of the labor force is engaged in unpaid family work, $19 \%$ work for private organizations, $9 \%$ is employed by government institutions, and a further $9 \%$ engaged in family owned enterprises, producing goods of various kinds for the local market [26]. Trundel \& Mcevoy [28], emphasize that less than $50 \%$ of households in the 'hotspots' have cash income.

Kaibia Valley, an urban community, is located in the central part of Honiara, situated along a major valley. Population density is estimated at 108 persons/hectare. The settlement is vulnerable to erosion and landslides, during the torrential tropical rain seasons, washing waste and debris down the valley, and posing serious health hazards to the community and neighboring settlements. Economic activities in the community is quite similar to other settlements in and around Honiara, ranging from unpaid family work, small road-side commercial activities, mainly the sale of betel nuts, merchandise, and consumables, with a small proportion engaged in formal, private and government, paid employment [16].

Tuvaruhu (Zone 5), the last of five communities in the larger Tuvaruhu enclave, is a peri- urban settlement, sitting along the upper end of the Mataniko river. The population density is estimated at 116 persons/hectare, with the population largely engaged in the informal sector [16]. Settlement pattern in this community, like others described in this paper, is unplanned, with houses sitting on hill escarpments, overlooking the Mataniko River valley. Domestic waste from houses along the escarpments are often washed down the Mataniko river, flowing down to settlements downstream, towards the ocean, including Lorde Howe.

Kakabona, otherwise known as Kakambona, is a peri-urban settlement sitting on the fringe of Honiara city (see Figure 1), located 4 kilometers (approximately 2.5 miles) west of Honiara, along the White River-Tandai Highway. The settlement is largely coastal, with a small portion stretching inland, away from the seashore. The settlement borders the Honiara City Council Ward of Nggosi [29]. Population density is estimated at 120 persons/hectare [16], with residents thriving on small-scale commercial activities along the Tandai Highway, trading in betel nut, vegetables, root crops, fish and flouriculture. Tourism is also a major commercial activity of residents in this community. Kakabona beaches are a major tourist attraction to Honiara residents and visitors (foreign and local), providing income to landowners along the beaches who charge nominal fees for access [30]. A general characteristic permeating most settlements in and around Honiara, is a high rate of youth unemployment, about $75 \%$, placing the state among countries with highest youth unemployment rate in the world [30].

Available official information about these settlements are rather scanty. What is clear though, is that settlement patterns, population structures, economic activities, demographics and other socio-economic structures are similar across the communities. Evans [30], for example, estimate that about 37\% of the workforce in these settlements is engaged in the informal sector, earning their livelihood through the sale of betel nuts, cigarettes, fruits and vegetables. Further to that, it is suggested that in Tuvaruhu, Kaibia, and elsewhere, economic activities such as carpentry, electrical work, repairs, and tradesmanship activities, are common across most age groups [30].

Municipal waste collection in Honiara, and its environs, is performed under a common developing country model of central waste collection points, on 'need' basis, and sometimes at random. These collection points are generally sited along main streets and convenient places for ease of collection, largely due to congestion and lack of motorable access roads into the communities. Barbara et al. [31], for example, reveal that waste and sanitation services remain patchy in urban settlements in Honiara. The poor distribution of such services worsens the waste management challenge, particularly in peri-urban areas, including Kakabona, Tuvaruhu (Zone 5), and others. Focus group discussions also cite open defecation into the sea and water bodies as a major problem in the settlements, an assertion supported by Munro \& Carpenter [27].

\section{Methods}

The study employs structured questionnaires, field observations, focus group discussion and document review, to obtain quantitative and qualitative data. To gain in-depth appreciation of the social, behavioral and attitudinal issues around the subject, obtaining information from opinion leaders and experts from the line ministry, the ministry of environment, was considered a vital complement to the survey instrument. In addition, the challenge of obtaining sufficient official records on the selected sites, dictated that a combination of methods be adopted in the data gathering process. Two main analytical methods, descriptive statistics and multi-variate regression, are used to analyze the data and draw inference about the parameters of interest.

\section{Analytical framework}

Descriptive and inferential statistical methods are used to analyze different aspects of solid waste generation, assess community waste management techniques, and make important deductions. These include: estimates of weekly household waste quantities (volumes); behavioral and attitudinal challenges, such as willingness to purchase less of disposable plastic products; concerns about environmental pollution and health hazards; 
characterization of waste types; waste disposal methods; wasterelated health challenges; damage cost to households (i.e., working-time lost and waste-related health expenditures); as well as waste minimization methods (i.e., waste-sorting, campaign and awareness programs).

\section{Empirical methods}

To help address the main objective of the study, i.e., establish the volume of waste generated and the associated attitudinal, behavioral, and other related factors, two separate multi-variate regression models are specified. The first model is specified in its general form as:

$$
H h_{v o l}=\beta_{0}+\sum_{i=1}^{k} \beta_{i} X_{i}+\varepsilon_{i}
$$

In this specification, Hhvol, is average weekly household waste volume; $X i$, vector of explanatory variables; and " $\varepsilon_{p}$, unobserved disturbances (error terms). The vector of explanatory variables include: household size (Hh_size), average weekly household expenditure (Hh_wkly.exp), waste-sorting (W_sorting), willingness to purchase less of disposable plastic products (Less_plastic), frequency of emptying household waste bin (Bin_emptying), environmental awareness (Env_awareness), and ownership of private business enterprise (B'sness_ownership). These are factors considered, a priori, significant drivers of changes in volume of waste generation at the household level. To ensure that multi-colinearity is not a challenge in the model, variance inflation factors (VIFs) were calculated. The VIF values ranged between 1.019 and 1.093, indicating that multi-colinearity is not a concern among the predictors. Given the belief that waste generation may have some significant impact on economic wellbeing of households, it is important to establish the relationship, if any, between household income and waste-related variables. To do this a second, and separate, model is specified as:

$$
H h_{i n c}=\beta_{0}+\sum_{i=1}^{k} \beta_{i} X_{i}+\varepsilon_{i}
$$

In this equation Hhinc, is average weekly household income. In addition to some of the explanatory variables in Equation 1, which are also included in this model, other explanatory variables in Equation (2) include: age (Age), education (Education), environmental concern (Env_concern) and working time lost (Time_lost). Inclusion of these variables in the models is informed by economic theory, and also identified in the waste management literature as challenges related to poor waste management. The VIF values for the predictors in this model ranged between 1.011 and 1.138; also indicating that multi-colinearity is not a challenge in the model. In addition to the theoretical underpinning, the intuition behind the inclusion of some of the variables is informed by the country context. For example, time lost in attending to health issues, either taking care of oneself or a sick family member, is assumed to impact household income in one way or the other.

Effort was made to capture community-specific characteristics in the models by including community dummies. However, preliminary results obtained from the inclusion of such variables were not statistically significant and so were excluded. In addition, interactive terms are not included in the models because even though multi-colinearity was not a problem in the models, preliminary results from their inclusion were also not statistically significant.

\section{Data}

The survey was conducted between September and November, 2017, in five urban and peri-urban communities in and around Honiara. Quantitative and qualitative data were obtained by a combination of methods, including structured questionnaires, field observations, focus group discussion and document review. A multi-stage sampling procedure was used to collect the data. First, the communities were purposefully selected. These communities possess typical characteristics of the study objective. Whereas Kakabona and Tuvaruhu (Zone 5) are atypical of peri-urban settlements in the Solomon Islands, Fishing Village, Lorde Howe and Kaibia Valley are well within the boundaries of the city and are characteristic of urban settlement in Honiara. These communities possess all the characteristics of waste management challenges in and around Honiara; congestion, lack of motorable access to households, inadequate solid waste management facilities, peculiar behavioral and attitudinal challenges, among others.

Second, the total sample size of $300,57 \%$ of the total sample space (526 households), was proportionally selected according to the total number of households in each community, using community leaders' household records. This means that each community was allocated a specific sample size, within the total sample of 300 , proportionate to the total number of recorded households in the community. Current population data for each community was not immediately available; last census was in 2009. A chi-square test to verify the representativeness of the sample, failed to reject the null hypothesis that the sample proportion is equal to the population proportion $\left(\chi^{2}=4: 033 ; p=\right.$ 0:401).

Third, one representative from each household was then selected, at random on site, (i.e., without prior notification), from the sample for each community. According to the available census records at the time of data collection, average household size in Honiara was about 7 persons [16]. Added to this, only one respondent was selected from each household, so the use of number of households as sample space was not expected to pose any analytical challenge. Structured questionnaires were pretested in Vura community, an urban settlement in Honiara, with similar characteristics as those used in the actual data collection. The questionnaires were administered randomly, skipping houses in between, in each community with the help of community chiefs, and supervised by trained enumerators. The method has proved successful in other studies including, Vidanaarachchi et al. [33], Okot-Okumu \& Nyeje [23], and others. 
The questionnaires covered household demographics and characteristics, waste generation (waste types and volumes), household waste management (waste handling, sorting, and disposal methods), environmental awareness, attitude and behavior in household waste management, waste-related health challenges, as well as economic loss (working time and income loss). Due to budgetary and other resource constraints, waste volumes were estimated. Using developing country and regional household daily per capita averages as guide ${ }^{2}$, a weekly household average was established and used to determine intervals for respondents to make relevant volume choices. Enumerators explained and demonstrated the weight measurements, to give respondents fairly reasonable impression of their weekly waste volume generation.

Focus group discussions, based on structured and semistructured interviews with key informants (including community leaders and other opinion leaders, policy makers, environmental experts from the Ministry of Environment and Honiara Municipal Council) formed part of the primary data collection process. Technical reports from the Ministry of Environment, Environmental Acts, and other research work on the subject in the Solomon Islands, were used to complement field observations and focus group discussions.

\section{Results and Discussion}

The analyses are presented in two parts. The first discusses descriptive statistics of solid waste categorization, volume estimation, disposal methods, awareness and behavioral tendencies of solid waste management, and the socio-economic cost variables of poor waste management. The second analyzes results of the multi-variate regressions.

\section{Descriptive results}

Solid waste was classified into solid, hazardous, and waste of multiple nature (Table 1). These three broad groupings follow categorizations in the literature $[7,9,23]$, and also represent the general nature of waste generation in the Solomon Islands. Solid waste comprises of mainly paper, fabrics, organic materials, plastics, bottles, other glass and aluminum wares. On average $92 \%$ of waste generated in the communities is of solid nature, nearly $2 \%$ hazardous (disposable health materials, chemical wastes, etc) and about $6 \%$ of multiple type (cosmetic waste, expired medical products, expired packaged liquid products, etc.) (Table 1). Mean weekly household waste volume is estimated at about $22 \mathrm{kgs} /$ household, with lower and upper bias corrected limits of 20.17 and $23.60 \mathrm{kgs}$., within $95 \%$ confidence intervals, based on 1000 bootstrap iterations (Table 2). This translates into a daily average estimate of about $0.45 \mathrm{kgs}$. per capita, based on the average household size of about 7 (Table 3), using 7-day week. This is consistent with developing country averages and averages found in the region [23,33,34]. Per capita daily waste volume generated varies across the globe. In developing countries, per capita average daily waste volume in urban centers is estimated between 0.4 and $0.6 \mathrm{~kg}$ [34]. For example, in municipal cities in Uganda, Okot-Okumu \& Nyeje [23] find the daily average per capita waste volume to be between 0.3 and $0.66 \mathrm{kgs}$. The quantity and reliability of data on urban waste generation in the Pacific region, according to Woodruff [9], remain highly variable, estimating the average per capita daily volume at $0.45 \mathrm{kgs}$. Lal et al. [7] put the weekly average household volume for non-indo Fijians at $15 \mathrm{kgs}$. Using the average household size of about 5 for this group [35], translates into about $0.43 \mathrm{kgs}$ per capita, quite similar to that established in this study.

Table 1: Waste Category Distribution by Community.

\begin{tabular}{|c|c|c|c|c|c|c|c|}
\hline \multirow{3}{*}{ Community } & \multicolumn{6}{|c|}{ Waste Distribution by Category } & \multirow{3}{*}{ Total } \\
\hline & \multicolumn{2}{|c|}{ Solid } & \multicolumn{2}{|c|}{ Hazardous } & \multicolumn{2}{|c|}{ Multiple } & \\
\hline & Count & $\%$ & Count & $\%$ & Count & $\%$ & \\
\hline Fishing Village & 14 & 87.5 & 0 & 0 & 2 & 12.5 & 16 \\
\hline Lorde Howe & 162 & 94.7 & 3 & 1.8 & 6 & 3.5 & 171 \\
\hline Kakabona & 39 & 97.5 & 0 & 0 & 1 & 2.5 & 40 \\
\hline Kaibia Valley & 38 & 86.4 & 1 & 2.3 & 5 & 11.3 & 44 \\
\hline Tuvaruhu (Zone 5) & 23 & 79.3 & 1 & 3.5 & 5 & 17.2 & 29 \\
\hline Total & 276 & 92 & 5 & 1.7 & 19 & 6.3 & 300 \\
\hline
\end{tabular}

${ }^{2}$ For more details see: Zerbock [34]; Mathew [33]; Lal et al. [7]; Okot-Okumu and Nyeje [23]; Woodruff [9]. 
Table 2: Household Weekly Waste Volume.

\begin{tabular}{|c|c|c|c|c|}
\hline \multirow{3}{*}{ Description } & \multirow{3}{*}{ Statistic (SD) } & \multicolumn{3}{|c|}{ Bootstrap } \\
\hline & & \multirow{2}{*}{ Bias } & \multicolumn{2}{|c|}{ BCa 95\% Confidence Interval } \\
\hline & & & Lower (L) & Upper (U) \\
\hline \multirow{2}{*}{ Mean } & 21.87 & 0.05 & 20.17 & 23.60 \\
\hline & $(13.994)$ & $(-0.013)$ & $(12.984)$ & $(14.925)$ \\
\hline [Min; Max] & {$[10.00 ; 50.00]$} & - & - & - \\
\hline Median & 20 & -0.565 & - & - \\
\hline Mode & 10 & - & - & - \\
\hline
\end{tabular}

Note: Waste Volume is estimated in Kilograms/week.

Confidence intervals are based on 1000 bootstrap iterations.

$\mathrm{SD}$ is standard deviations (in parenthesis).

$\mathrm{BCa}$ is Bias-corrected and accelerated.

Table 3: Statistics of Household Size in Communities.

\begin{tabular}{|c|c|c|c|c|}
\hline \multirow{2}{*}{ Description } & \multirow{2}{*}{ Statistic (SD) } & \multicolumn{2}{|c|}{ Bootstrap } \\
\cline { 2 - 5 } & & \multirow{2}{*}{ Bias } & \multicolumn{2}{|c|}{ BCa 95\% Confidence Interval } \\
\cline { 2 - 5 } & 7.35 & 0.00 & $(3.311)$ & Lower (L) \\
\hline \multirow{2}{*}{ Mean } & $(3.934)$ & $(-0.023)$ & - & $(4.532)$ \\
\hline [Min;Max] & {$[1 ; 32]$} & - & 6.94 & - \\
\hline Median & 6 & 0.20 & - & 6.00 \\
\hline Mode & 6 & - & & - \\
\hline
\end{tabular}

Note: BCa is Bias-corrected and accelerated.

$\mathrm{SD}$ is standard deviations (in parenthesis).

Waste disposal in the communities takes various forms and include burning (25.7\%), burying in homesteads (7\%), multiple methods (57\%), and other non-explicit miscellaneous forms (7\%), with only a small proportion, about 3\%, of recycle/reuse (Table 4). Multiple methods are random forms of disposal, which include dumping in neighborhoods under cover of darkness, dumping in water bodies (the sea and river), taking to designated collection points at random, etc. Field observation, residents' accounts, and focus group discussions, indicate that illegal dumping of waste in the communities, particularly in and around water bodies, are a common practice. Besides the practice being harmful to human health and the environment [36], low temperature incineration is found to release carcinogenic and harmful chemicals into the atmosphere and contribute to climate change challenges. Even though waste incineration is argued to have waste reduction benefits in small island nations where land constraint is a challenge, Woodruff [9] emphasizes that the practice is not without economic challenge. Indiscriminate disposal of plastic materials in the neighborhoods is reported at $8.3 \%$, about $23 \%$ buried in homesteads, and a good proportion of plastic waste, nearly $49 \%$, never finding its way to the central municipal collection points (Table 4), not to mention the fact that the central collection system in itself is porous and ill managed.

Table 4: Waste Disposal Methods.

\begin{tabular}{|c|c|c|c|c|c|}
\hline \multicolumn{3}{|c|}{ All Waste Types } & \multicolumn{3}{|c|}{ Plastic Waste } \\
\hline Disposal Method & Count & $\%$ & Disposal Method & Count & $\%$ \\
\hline Burn & 77 & 25.7 & Throw in neighborhood & 25 & 8.3 \\
\hline Bury in Compound & 21 & 7.0 & Bury in homestead & 69 & 23.1 \\
\hline Recycle/Reuse & 10 & 3.3 & \multirow{2}{*}{ Taken to Designated Collection points } & \multirow{2}{*}{154} & \multirow{2}{*}{51.3} \\
\hline Multiple Methods & 171 & 57.0 & & & \\
\hline Other & 21 & 7.0 & Other & 52 & 17.3 \\
\hline
\end{tabular}

Note: 'Other' disposable methods include: dumping in nearby water bodies,

at the roadside under cover of darkness, used as fuel, etc. 
Households use various kinds of objects as waste receptacles prior to final disposal, and these include plastic bags, polypropylene sacks, metal containers, paper boxes, as is the case elsewhere in the developing world [37]. Though $86 \%$ of respondents claim to have these pre-disposal receptacles, focus group discussions show that most of the objects are, in themselves, of waste nature and are eventually disposed off like any other solid waste, often in indiscretionary manner, in neighborhoods and in river bodies. Poor waste disposal is a formidable challenge in the region and elsewhere in the developing world $[7,9,14,33,38]$. For example, Woodruff [9] emphasizes that waste dumping and burning is a serious cause of environmental and ecological destruction and threats to sources of economic livelihood.

Another concern is the behavioral tendencies towards the purchase and disposal of disposable plastic products. Plastic waste disposal has generated international concern in recent times. To understand attitudinal issues relating to this, this

Table 5: Plastic Products Purchase. study sought to establish willingness to purchase less of plastic products. The study finds that majority of respondents (92\%) expresses the willingness to purchase less of such products. Of the small proportion who are unwilling to purchase less of the product, about $54 \%$ cite habit (over dependence) as reason, with about a quarter (25\%), citing limited options as the excuse to want to purchase more (Table 5). Discussions with community chiefs and focus groups identify population increase as major factor exacerbating the waste management challenge, and particularly lamenting the problem of open defecation and indiscriminate waste disposal along the coast. MECDM [17] collaborates focus group's assertion, adding that provision of waste collection facilities in designated points within the communities has been inadequate, and cites poor accessibility to most communities as one of the main challenges hindering the Honiara City Council (HCC) from providing such facilities to households, in urban and peri-urban communities.

\begin{tabular}{|c|c|c|c|c|}
\hline \multicolumn{2}{|c|}{ Willingness to purchase less of plastic products } & \multicolumn{2}{c|}{ Reasons for unwillingness to purchase less } \\
\hline \multirow{2}{*}{ Response } & \multicolumn{2}{|c|}{ Distribution } & Reasons & Distribution (\%) \\
\cline { 2 - 5 } & Count & \% & Over Dependence (Habit) & 25 \\
\hline Yes & 276 & 82 & Limited Options & 20.83 \\
\hline No & 24 & 100 & Unaware of Env. Impact & 100 \\
\hline
\end{tabular}

Environmental awareness and dangers of poor waste management appear to be widespread. A high proportion of respondents $(92.3 \%)$ has received environmental awareness education in one form or another: through awareness campaigns, including radio programs, schools, churches, friends, or relatives. Knowledge about the dangers of poor waste is equally high. For example, $85 \%$ of respondents are aware and believe that hazardous waste can cause serious damage to the environment as well as create health problems (Table 6). It is, however, not clear

Table 6: Awareness, Knowledge of Waste Hazards and Information Flow to Communities.

\begin{tabular}{|c|c|c|c|c|c|}
\hline \multicolumn{3}{|c|}{ Awareness Education and Knowledge of Hazards } & \multicolumn{3}{|c|}{ Frequency of Information Flow to Communities } \\
\hline Response & Awareness Education Received (\%) & $\begin{array}{c}\text { Knowledge of Waste Hazards } \\
\text { to the Environment (\%) }\end{array}$ & Period & Count & $\%$ \\
\hline Yes & 92.3 & 85 & Up to 6 Months & 118 & 39.3 \\
\hline No & 7.7 & 15 & A Year and Over & 180 & 60 \\
\hline \multirow[t]{2}{*}{ Total } & 100 & 100 & Other & 2 & 0.7 \\
\hline & & & Total & 300 & 100 \\
\hline
\end{tabular}

In addition to health-related challenges of poor waste management, the literature highlights various socio-economic problems. The study identifies three main socio-economic issues to include frequency of seeking medical attention, working time lost and expenditures, related to solid waste-related health challenges. Poor waste management-related health problems identified include allergies (skin, eye and nasal irritation); whether the high level of concern (79\%) about waste management challenges in the communities is explained by widespread environmental awareness (Table 7), or that communities have woken up to some shocking realities on ground. On the other hand, awareness information flow appears to be highly infrequent. Whereas only $39 \%$ of respondents received any form of waste management information in the last six months, over $60 \%$ last received one form of awareness information or another, a year or more ago (Table 6).

gastrointestinal infectious diseases, such as cholera, dengue fever, cancer, etc; and multiple health complications. These are of significant proportions among respondents, ranging from $20 \%$, in the case of gastrointestinal and infectious diseases, about 31\% of allergies, to $43 \%$ multiple health cases (Table 8). Community perception of waste-related health challenges is well documented in the literature (See for example, Torres \& Ramos [36] and the 
references there in). On average $76 \%$ of respondents, or members of their households, are found to visit health facilities up to 3 times, and about $14 \%$ visiting 4 or more times (Table 9) in a month, as a result of waste-related health issues. In a closely knit society,

Table 7: Community Concerns. like the Solomon Islands, the implication is that immediate and external family members, are directly or indirectly affected in diverse ways, by providing support of one kind or another.

\begin{tabular}{|c|c|c|}
\hline \multicolumn{2}{|c|}{ Community Concerns about Waste Management Challenges } \\
\hline Level of Concern & Count & Distribution \% \\
\hline Unconcerned & 17 & 5.7 \\
\hline Indifferent & 1 & 0.3 \\
\hline Somewhat Concerned & 44 & 14.7 \\
\hline Very Concerned & 237 & 79.0 \\
\hline Unsure & 1 & 0.3 \\
\hline Total & 300 & 100 \\
\hline
\end{tabular}

Table 8: Waste Related Health Challenges.

\begin{tabular}{|c|c|c|}
\hline Health Challenge & Count & \% \\
\hline Allergies (skin, eye, and nose irritation) & 92 & 30.7 \\
\hline Gastro-intestinal and infectious diseases (e.g., cholera, dengue fever, cancer, etc) & 60 & 20.0 \\
\hline Multiple health problems & 129 & 43.0 \\
\hline Other & 19 & 6.3 \\
\hline Total & 300 & 100 \\
\hline
\end{tabular}

Table 9: Working Time lost and Frequency of Visits to Medical Facilities.

\begin{tabular}{|c|c|c|c|c|c|c|c|}
\hline \multicolumn{5}{|c|}{ Statistics of HH Working Time lost in a Year } & \multicolumn{3}{|c|}{ HH Visits to Health Facilities (in a month) } \\
\hline \multirow{3}{*}{ Description } & \multirow{3}{*}{ Statistic (SD) } & \multicolumn{3}{|c|}{ Bootstrap } & \multirow{3}{*}{ No. of Visits } & \multirow{3}{*}{ Count } & \multirow{3}{*}{$\%$} \\
\hline & & \multirow{2}{*}{ Bias } & \multicolumn{2}{|c|}{ BCa $95 \%$ Confidence Interval } & & & \\
\hline & & & Lower (L) & Upper (U) & & & \\
\hline \multirow{2}{*}{ Mean } & 3.76 & 0.004 & 3.42 & 4.13 & 1 to 3 & 228 & 76.0 \\
\hline & $(3.113)$ & $(-0.020)$ & $(2.532)$ & $(3.656)$ & 4 to 5 & 31 & 10.3 \\
\hline [Min ; Max] & {$[2.5 ; 20.0]$} & & & & $5+$ & 12 & 4.0 \\
\hline Median & 2.5 & 0.000 & & & Other & 29 & 9.7 \\
\hline Mode & 2.5 & & & & Total & 300 & 100 \\
\hline
\end{tabular}

Note: 1 . Time lost is computed in days.

2. BCa is Bias-corrected and accelerated.

A further dimension of this, is that significant amount of working time is lost, either directly by the affected or close family members. With bias corrected 95\% confidence interval, after 1000 bootstrap iterations, results show that average working time lost, in a year, falls between 3 to 4 days, with 2.5 working days being the mode (Table 9). The other equally compelling economic cost is the financial implication. A 1000 bootstrap iterations, with bias corrected $95 \%$ confidence interval, shows that on average, household expenditure on waste-related health cases falls between SBD 1620 and 1749 annually (Table 10). In a country where average (median) national annual per capita income and expenditure are $\operatorname{SBD}^{3}$ 10, 067 (SBD 5, 798) and SBD 9, 467 (SBD 6, 856), respectively [16], this is rather a huge economic cost for poor households.

\section{Multi-variate analysis}

Two models were specified to help explain the different aspects of waste management in the selected communities: waste volume and household income models (11). In the waste volume model, predictors found statistically significant include

${ }^{3} \mathrm{SBD}$ is the Solomon Islands' national currency; the Solomon Islands' Dollar is approximately 8:1 USD atcurrent exchange rate. 
household size (Hh_size), weekly household expenditure ( $\mathrm{Hh}$ wkly_exp.), waste sorting (W_sorting), willingness to purchase less of disposable plastic products (Less_plastic), and frequency of emptying household waste-bin (Bin_emptying). Contributions of household size and weekly household expenditure to waste volume are statistically significant, confirming findings in the literature. Household size and population increase are found to exert increasing pressure on waste generation (waste volume), in both developing and developed countries [39-41]. The findings of household expenditure, a directly related component of household income, is supported by other investigations in the literature. For example, Bhattarai [41] \& Chakrabarti and Sarkhel [42] find evidence to suggest that increase in per capita income contribute significantly to increase in waste generation. Demographic and socio-economic variables are generally found to affect solid waste management in one way or the other [43].

Table 10: Household Waste-related Health Expenditure (Annual).

\begin{tabular}{|c|c|c|c|c|}
\hline \multirow{3}{*}{ Description } & \multirow{3}{*}{ Statistic (SD) } & \multicolumn{3}{|c|}{ Bootstrap } \\
\hline & & \multirow{2}{*}{ Bias } & \multicolumn{2}{|c|}{ BCa 95\% Confidence Interval } \\
\hline & & & Lower (L) & Upper (U) \\
\hline \multirow{2}{*}{ Mean } & 1685.46 & -2.045 & 1620.08 & 1749.01 \\
\hline & $(625.031)$ & $(-14.785)$ & $(427.108)$ & $(780.824)$ \\
\hline [Min; Max] & {$[1500 ; 6000]$} & - & - & - \\
\hline Median & 1500 & 0.000 & - & - \\
\hline Mode & 1500 & - & - & - \\
\hline
\end{tabular}

Note: Expenditure is in Solomon Islands Dollars (Approximately 8 to 1 USD at the time of writing;

$\mathrm{BCa}$ is Bias-corrected and accelerate; SD is standard deviations (in parenthesis).

Attitudinal and behavioral variables, such as waste sorting, willingness to purchase less of disposable plastic products and emptying of household waste-bin, show statistically significant reduction in waste generation at the household level. Waste sorting is also found in the literature to be significant in minimizing residential waste and is recommended as a policy instrument to encourage waste reduction at the household level [7]. Environmental awareness among respondents, though not statistically significant, has the expected sign in waste reduction. These findings are important in helping policy makers identify appropriate incentive mechanisms to address the attitudinal and behavioral challenges. Incentive mechanisms are found to work by altering the structure of pay-offs that agents face, thereby creating incentives for individuals or firms to voluntarily change their behavior [44].

The variable, business ownership (B'sness_ownership) was included in the models to verify if there is any relationship between households' engagement in economic activities in the communities and solid waste generation. One main economic enterprise found in these communities is the sale of betel nut. The husks of this intoxicating nut, chewed together with lime at home, in the streets, and at work places, litter the environment, often in heaps, hence the attempt to investigate the possible relationship with waste volume at the household level. Though the signs were positive, showing contribution to increases in waste generation, the variable was not statistically significant.

In order to establish possible effect waste-related variables may have on household income, the household income model was considered (Table 11). The main variables of interest are the attitudinal and behavioral variables, including willingness to purchase less disposable plastic materials, concern for the environment, and working time lost (an economic cost variable). Willingness to purchase less disposable plastic materials is statistically strongly significant and in the negative direction, showing adverse effect on household income. A possible explanation is that available alternatives to disposable plastic bags and packaging materials (or polypropylene materials in general), such as paper, longer lasting fabric or jute, more durable bio-degradable packaging materials, etc, are currently either few or unavailable, and where available rather costly. This, therefore, increases household expenditure and exerts downward pressure on household income. In this study, respondents who are unwilling to purchase less of plastic products cite lack of affordable alternatives as a major reason. Currently, all purchases from shops are, literally, either in plastic packages or packed in plastic shopping bags after purchase.

Environmental awareness and concern for the environment, are found to contribute to increases in household income and are statistically strongly significant. This could mean that raising awareness of the dangers of poor waste management among households, possibly help individuals make sound decisions about waste generation that may help cut down expenditures and make savings. A similar argument can be made for the positive contribution of concern for the environment. Awareness continues to be a key policy instrument in developing countries. In South Africa, for example, awareness education is identified as key in the national waste management tool kit [45]. The effect of working time lost due to waste-related challenges is not 
significant. This is not surprising in the context of the society in which this study is conducted. In a society where absenteeism is endemic, working time lost, due to environmental challenges are not likely to exert significant pressure on income. Further to that, in a closely knit society such as the Solomon Islands, the strong family support system, the wantok system, may augment income loss due to working time lost as a result of a health challenge; i.e., receiving monetary and other material support from wantoks in times of need.

Table 11: Household Waste \& Income Models.

\begin{tabular}{|c|c|c|c|}
\hline \multicolumn{2}{|c|}{ Waste Volume Model } & \multicolumn{2}{|c|}{ Income Model } \\
\hline Explanatory Variable & Dependent Variable & Explanatory Variable & Dependent Variable \\
\hline \multirow{2}{*}{ Hh_size } & $0.958^{* * *}$ & \multirow{2}{*}{ Age } & -4.42 \\
\hline & $(4.704)$ & & $(-1.203)$ \\
\hline \multirow{2}{*}{ Hh_wkly_exp. } & $0.005^{* * *}$ & \multirow{2}{*}{ Education } & $15.38^{*}$ \\
\hline & $(2.976)$ & & $(1.730)$ \\
\hline \multirow{2}{*}{ W_sorting } & $-5.751^{* * *}$ & \multirow{2}{*}{ Less_plastic } & $-346.01^{* * *}$ \\
\hline & $(-2.810)$ & & $(-2.877)$ \\
\hline \multirow{2}{*}{ Less_plastic } & $-9.00^{* * *}$ & \multirow{2}{*}{ Env_awareness } & $283.05^{* *}$ \\
\hline & $(-2.693)$ & & $(2.134)$ \\
\hline \multirow{2}{*}{ Bin_emptying } & $-2.105^{* *}$ & \multirow{2}{*}{ Env_concern } & $117.248^{* * *}$ \\
\hline & $(-2.088)$ & & $(2.822)$ \\
\hline \multirow{2}{*}{ Env_awareness } & -5.34 & \multirow{2}{*}{ B'sness_ownership } & $189.86^{* * *}$ \\
\hline & $(-1.579)$ & & $(2.664)$ \\
\hline \multirow{2}{*}{ B’sness_ownership } & 1.299 & \multirow{2}{*}{ Time_lost } & -2.39 \\
\hline & $(0.702)$ & & $(-0.233)$ \\
\hline \multirow{2}{*}{ Constant } & $38.055^{* * *}$ & \multirow{2}{*}{ Constant } & $465.62 *$ \\
\hline & $(6.345)$ & & $(1.780)$ \\
\hline AIC & 1332.123 & AIC & 3453.615 \\
\hline $\mathrm{BIC}$ & 1360.578 & $\mathrm{BIC}$ & 3482.549 \\
\hline R2 & 0.2 & $\mathrm{R} 2$ & 0.1 \\
\hline F-statistic & 8.76 & F-statistic & 4.289 \\
\hline (p-value) & 0 & (p-value) & 0 \\
\hline Obs. & 300 & Obs. & 300 \\
\hline
\end{tabular}

Note: t-statistics are in parenthesis, ${ }^{* *} p<0.01,{ }^{* *} p<0.05,{ }^{*} p<0.10$.

\section{Concluding Remarks}

Poor waste management in developing nations has been attributed to stylized challenges, including poor waste collection methods, poor and inadequate equipment, lack of resources, awareness, education, and many others. In the case of the Solomon Islands, for example, limited awareness and knowledge, inadequate scientific based information to guide policy, coupled with lack of cooperation and poor attitudinal problems, both at household and private business levels, are considered serious factors exacerbating the challenge. On the other hand, quantification of solid waste generation in urban and peri-urban centers across the developing world, alongside the related attitudinal, social and economic impacts, remain largely unknown. Attitudinal and behavioral challenges in particular, have not received adequate attention, at all levels. Local environmental practitioners and community leaders have often cited the latter as a challenge, but that remains anecdotal and not scientifically established. This paper has attempted to estimate the average waste volume generated at household level, teased out the socioeconomic and behavioral challenges of solid waste management, and provided scientific evidence to assist policy makers and managers identify the challenges and address them. This is a major contribution to the waste management debate, at least in the context of the Solomon Islands.

Incentivizing households to adopt responsible attitudes towards waste management, through various means, is likely to help improve the waste menace and its associated environmental, socio-economic and health challenges. Establishment of reward 
systems and norms as incentives that will name and shame offenders, are considered instrumental in promoting attitudinal change and encourage household participation in waste management. Churches and schools are observed as important partners in this drive. Awareness programs, for example, are well documented in the literature as a good incentive mechanism to help address the waste problem. This can take on diverse forms, including community self-help programs, through regular community clean-up campaigns, as well as effective law and regulatory enforcement. This process can also increase awareness information flow among the citizenry. Awareness continues to be a key policy instrument in developing countries, but the frequency of information dissemination needs to be increased to ensure effectiveness in order to achieve desired results. For example, this paper finds that awareness information flow in urban and periurban centers is highly infrequent.

Formalizing waste minimization and recycling policies, laws, bi-laws, regulations, as well as enhancing existing policy and regulatory frameworks are considered essential to the success of confronting the waste management challenge. Along this, waste sorting can be advocated to encourage recycling and composting which have been found, in this paper and others in the literature, to be significant measures in promoting effective solid waste management.

This study shows apparent individual willingness to make environmentally friendly and sustainable choices, but alternatives are either not available, or where available, costly and, beyond the means of the poor majority. Attitudinal and behavioral variables have been found, in this study, to significantly affect waste management and, therefore, require suitable polices to promote appropriate human behavior in the effort to address the solid waste menace. Further work to unearth and establish the causal relationship between attitudinal and behavioral challenges, on one hand, and waste management at the household and community levels, on the other, is encouraged.

\section{Acknowledgment}

i. Sincere appreciation goes to the Office of Research and Post Graduate Studies of the Solomon Islands National University (SINU), for providing financial support to conduct this study. My gratitude also goes to community leaders, opinion leaders, environmental expert from the ministry of environment, climate change and disaster management (MECDM), and residents of Fishing Village, Lorde Howe, Kakabona, Kaibia Valley and Tuvaruhu (Zone 5), for their time and support during the data collection exercise. Further appreciation goes to Vura community for participating in the pre-test of the survey instrument.

\section{References}

1. Venkateswaran S (1994) Managing waste: Ecological, economic and social dimensions. Economic and Political Weekly,29 (45/46): 5-12.
2. Moriguchi Y (2001) Rapid socio-economic transition and material flows in Japan. Population and Environment 23(1): 105-115.

3. UNEP (2004) The use of economic instruments in environmental policy: Oppportunities and challenges. Technical report, United Nations Environment Programme, Geneva.

4. Miezah K, Obiri-Danso K, Kadar Z, Fei-Baffoe B, Mensah MY (2015) Municipal solid waste characterization and quanti_cation as a measure towards effective waste management in Ghana. Waste Management 46: 15-27.

5. Khajuria A, Yamamoto Y, Morioka T (2010) Estimation of municipal solid waste generation and landfill area in Asian developing countries. Journal of Environmental Biology 31(5): 649-654.

6. Bartone CL, Bernstein JD (1993) Improving municipal solid waste management in third world countries. Resources, Conservation and Recycling 8(1-2): 43-45.

7. Lal P, Tabunakawai M, Singh SK (2007) Economics of rural waste management in the Rewa Province and development of rural solid waste management for Fiji. Technical Report 57, Pacific Islands Forum Secretariat, Secretariat of the Pacific Regional Environmental Programme and the Government of Fiji (International Waters Project).

8. UN-Habitat (2010) Solid Waste Management in the World's Cities. (3 $3^{\text {rd }}$ edn), Guternberg Press, Malta.

9. Woodruff A (2014) Solid waste management in the Pacific: Appropriate technologies. Technical Report, ARM 146620-2, Urban, Social and Public Management Division, Asian Development Bank, Publication Stock, No. ARM 146620-2.

10. Cointreau-Levine SJ (1994) Private sector participation in municipal solid waste management in developing countries. In: The formal sector, urban management programme policy paper.no. 13, vol. 1. Research report, no. 13, vol. 1, World Bank, Washington.

11. Guerrero LA, Maas G, Hogland W (2013) Solid waste management challenges for cities in developing countries. Waste Management 33(1): 220-232.

12. Grazhdani D (2016) Assessing the variables affecting the rate of solid waste generation and recycling: An empirical analysis in Prespa Park. Waste Management 48: 3-13.

13. Manaf LA, Samah MAA, Zukki NIM (2009) Municipal solid waste management in Malaysia: Practices and challenge. Waste Management 29(11): 2902-2906

14. Marshall RES, Farahbakhsh K (2013) Systems approach to integrated solid waste management in developing countries. Waste Management 33(4): 988-1003.

15. SIG (2016) National waste management and pollution control strategy 2017 - 2026, draft. Solomon Islands Government.

16. SINSO (2015) Solomon Islands 2012/13 household income and expenditure survey: National analytical report. vol 1. Technical Report, Solomon Islands National Statistical Office (SINSO), Ministry of Finance and Treasury, Solomon Islands Government, Honiara.

17. MECDM (2015) Mataniko environment baseline, draft report. Technical Report, Ministry of Environment, Conservation, Disaster Management and Meteorology (MECDM), Solomon Islands Government.

18. Price S, Beeson A, Fardin J, Radford J (2015) Environmental Law in Solomon Islands. Ligare Pty Ltd. 138-152 Bonds Road, Riverwood, NSW, Australia 2210.

19. Sinclaire E, Kannan K (2006) Mass loading and fate of perfluoroakyl surfacants in water treatment plants. Environmental Science and Technology 40(5): 1408-1414. 
20. Adebilu AA, Okenkule AA (1989) Issues on environmental sanitation of Lagos mainland, Nigeria. The Environmentalist 9(2): 91-100.

21. Achankeng E (2003) Globalization, urbanization and municipal solid waste management in Africa. In Proceedings of African Studies Association of Australasia and the Pacific: African on a global stage.

22. Kaseva ME, Mbuligwe SE (2005) Appraisal of solid waste collection following private sector involvement in Dar-es Salaam City, Tanzania. Habitat International 29(2): 353-366.

23. Okot-Okumu J, Nyeje R (2011) Municipal solid waste management and decentralization in Uganda. Habitat International 35(4): 537-543.

24. Manga VE, Forton OT, Read AD (2008) Waste management in Cameroon: a new policy perspective? Resources, Conservation and Recycling 52(4): 592-600.

25. SIG (2009) Report on 2009 population and housing census, Honiara. Technical Report, Solomon Islands National Statistical Office, Ministry of Finance and Treasury, Honiara.

26. Rodil AS, Mias-Cea MAA (2014) Cities and climate change initiative, Honiara, Solomon Islands: Climate change vulnerability assessment. Technical Report, First Edition, UN-Habitat.

27. Munro J, Carpenter J (2016) Luxury and disturbances: Women's views on city life in Honiara settlements. Technical Report 30, SSGM In Brief 2016/30, Australian National University.

28. Trundel S, McevoyD (2016) Honiara urban resilience and climate action plan. Technica Report, UN-Habitat.

29. Hughes B, Hunt C, Curth-Bibb J (2013) Forging new conventional wisdom beyon international policing, learning from complex political realities. Nijhoff Publishers, Belgium.

30. Evans D (2016) Hardwork: Youth employment in Honiara, Solomon Islands. In Urban Development in Melanesia: Talk of the town, SSGM Discussion Paper 2016/7. State, Society and Governance. Coral Bell School of Asia and Pacific Affairs. Australia National University, College of Asia Pacific, Canberra ACT 0200.

31. Barbara J, Keen M, Carpenter J (2016) Visions for Henderson: A workshop on peri-urban growth in the Solomon Islands. resreport 32, SSGM In Brief 2016/32, Australian National University.

32. Vidanaarachchi CK, Yuen STS, Pilapitiya S (2006) Municipal solid waste management in the southern province of Sri Lanka: Problems, issues and challenges. Waste Management 26(8): 920-930.
33. Mathew V (2003) Solid waste management in Kottayam town. Research Report, Department of Chemistry, Baselius College, Kottayam 686001. Kerala Research Program on Local Level Development, Project No. 195/99.

34. Zerbock O (2003) Urban solid waste management: Waste reduction in developing nations.Technical report, Michigan Technlogical University, Michigan, U.S.A.

35. FBoS (2018) Fiji Bureau of Statistics. Fiji population and housing census, 2017. Technicalreport.19

36. Torres E, Ramos BTM (2004) Health risk perception of communities located in Metro Manila Airshed. Technical Report, Environment and Occupational Health Office, Department of Health, Manila, Philippines.

37. Musademba D, Musiyandaka S, Muzinda A, Nhemachena B, Jambwa D (2011) Municipality solid waste management (MSW) challenges of Chinhoyi Town in Zimbabwe: Opportunities of waste reduction and recycling. Journal of Sustainable Development in Africa 13(2).

38. Mataki M (2011) A Critical Assessment of the Paradigms for Solid Waste Management in Pacific Island Countries. PhD thesis, Murdoch University, Australia20.

39. Jenkins RR (1993) The Economics of Solid Waste Reduction. Number 248. Edward Elgar Publishing.

40. Beede DN, Bloom DE (1995) The economics of municipal solid waste. The World Bank Research Observer 10(2): 113-150.

41. Bhattarai RC (2000) Solid waste management and economics of recycling: A case of Kathmandu Metro City. Economic Journal of Development Issues 1(2):9-106.

42. Chakrabarti S, Sarkhel P (2003) Economics of solid waste management: A survey of existing literature. Technical report, Indian Statistical Institute, Economic Research Unit, Kolkata, India.

43. Richardson RA, Havlicek J (1974) An analysis of seasonal household solid waste generation. Southern Journal of Agricultural Economics 6: 143-165.

44. Perman R, Ma Y, Common M, Maddison D, McGilvray J (2011) Natural Resource and Environmental Economics. Pearson Education Limited, ( $4^{\text {th }}$ edn), Edinburg Gate, Harlow, Essex CM20 2JE, England.

45. Godfrey L (2008) Facilitating the improvement of waste in South Africa through national waste information system. Waste Management 28(9): 1660-1671.

\section{Your next submission with Juniper Publishers will reach you the below assets}

- Quality Editorial service

- Swift Peer Review

- Reprints availability

- E-prints Service

- Manuscript Podcast for convenient understanding

- Global attainment for your research

- Manuscript accessibility in different formats

( Pdf, E-pub, Full Text, Audio)

- Unceasing customer service

Track the below URL for one-step submission https://juniperpublishers.com/online-submission.php 